\title{
FACTORS INFLUENCING E-SERVICE SATISFACTION IN TERTIARY EDUCATION IN GHANA
}

\author{
Xiong Qiang ${ }^{1}$ \\ School of Management, \\ Jiangsu University, \\ Jiangsu, 301 Xuefu Road P.R China
}

\author{
Ran Kwabena Fosu Sarpong*2, \\ School of Management, \\ Jiangsu University, \\ Jiangsu, 301 Xuefu Road, \\ P.R China.
}

\author{
Takyi Kwabena Nsiah ${ }^{3}$, \\ School of Finance, \\ Jiangsu University, \\ Jiangsu, 301 Xuefu Road, \\ P.R China \\ *Corresponding author
}

\begin{abstract}
Empirical work on the quality, expectation, and loyalty of e-services and their implications on satisfaction in the sense of 'normal' service has not been carried out. With this in mind, this study analyzed the linkages between e-service quality (in this 'normal' service environment), e-service expectation, e-service satisfaction, and e-service usage frequency by using PLS-SEM-VB using questionnaire data collected from 360 students. The conclusions obtained suggested that the level of usage of E-service has only a positive direct impact on the quality of e-service and satisfaction of e-service. E-service expectations also have an indirect positive effect on e-service satisfaction through the frequency of use of the E-service. The consequence of these findings is that companies offering low-quality e-services are more likely not to satisfy their clients. In effect, will not affect their engagement but would still use the service for buying and re-purchasing purposes due to institutional purposes. The assumption in the case of the current study is that universities with better e-services should have students considering their e-services to be adequate and therefore consistent in using e-services to enhance learning and administrative communication.
\end{abstract}

\section{INTRODUCTION}

As a means of widening the market, web and internet innovation now serve as a vital resource for organizations to extend their operations and service offerings abroad at relatively lower costs (Swaid \& Wigand, 2009). As a result, e-services have escalated over the years and shifted the business dimensions for both local and international businesses ( $\mathrm{Li}, \mathrm{Liu}, \&$ Suomi, 2009) by emphasizing on high-quality offerings, customer expectations and convenience (Sohn \& Tadisina, 2008). Unlike the past where online presence was the prerogative of retail companies, e-service is increasingly being embraced by solely service organizations and governments to enhance the quality of their services (Kim-Soon et al.,
2014) rather than the mere online presence for informative purposes; which has provided room for confusion in today's conceptualization of e-services.

The justification for this study can be found in Kilburn and Kilburn's argument (2003) that, apart from imparting knowledge, universities often are businesses. That suggests they can not continue to overlook growing trends in the market for e-services from their customers (students) and better compete. Moreover, Cronin et al. (1992) conclude that one of the most important problems influencing corporate strategy today is the quality of service, and the value it gives to its users / customers. They argue that consumer expectations have been greatly affected thereby influencing satisfaction rates. Thus the 
standard of e-service can not be separated in this regard. According to Kim- Soon et al. (2014), universities have been at the frontline of online development mainly for educational and general populace admission purposes. Recent advances, even so, indicate that higher education institutions have now been going other than pure web presence to using the Internet network to exploit their resources, such as offering virtual classes to better serve the needs of both distant and on-campus students and faculty members (Kim-Soon et al., 2014; Sutarso \& Auharmdi, 2011). In addition to using e-services to eradicate administrative costs by having students to conduct such self-services online (such as course registration, lecturer assessment, etc.), universities are now breaking domestic parameters through eservices and thus through the competitiveness of educational institutions at home or abroad. It's not extraordinary, however, that online university courses advertisements are still appearing everywhere on almost every web page today.

In an e-commerce setting, the concept of eservice quality has been established to include providing superior customer experience in pretransaction, transaction, and post-transaction indicators (Zeithaml et al., 2002; and Santos, 2003). Even though the definition of quality and its calculation of services in relation to the SERVQUAL instrument has been explored in detail in multiple ways, its key constraint as addressed is its obvious lack of physical presence in e-services (Shapor et al., 2011; Cristobal et al., 2007; and Swaid \& Wigand, 2009). Consequently, the subject has recently gained notable attention in both academia and industry.

However, the concerns that remain to be discussed include; how much attention higher learning educational institutions will pay to the expectations of their users and quality of the eservices they offer; and whether or not higher learning institutions in developed countries can benefit from paying closer attention to enhancing the quality of the e-services they provide to their students. Regardless, the main objective of this study is to find out the relationship between e-service quality, expectation and frequency of use and impact on satisfaction students deriving from e-services and whether universities in Ghana can benefit from paying more attention to maximizing the quality of eservices they provide.

Most recent researches have been adopting SEM (structural equation modeling) to investigate the developments of e-services models in higher educational institutions worldwide (Henry et al., 2017) but this research uses PLS (Partial Least Squares) SEM-VB (Structural Equation Modeling Variance Based) to check an exploration model that is unique to previous literature.

A number of proposals are presented in the rest of this paper, based on literature. Subsequently, the research design of our empiric study is clarified and the review and results are discussed. The findings are then debated and the management consequences are formulated. Finally, the drawbacks of this analysis and the path for further studies are discussed.

\section{LITERATURE REVIEW}

According to (Kilbum and Kilburn's 2014) not only universities set up to combat literature, they are also business entities. It was inferred that universities cannot continue to neglect, and remain highly competitive, the developments in the e-services market for their customers (students). Whereas, the quality of service is among the most important issues impacting business model today. The interplay of eservice quality, expectation and frequency of usage and its impact on customer satisfaction has been argued with uncertainty. So in this sense e-service quality cannot be out of the way. According to KimSoon et al. (2014), higher learning institutions have been at the forefront of online activities for the purposes of information and access to the general public.Nevertheless, recent developments indicate that universities are now going beyond that of a simple online presence to use the Internet network to coordinate their capacity to meet the needs of both distant students and faculties on campus (Kim-Soon et al., 2014; Sutarso \& Auharmdi, 2011). Universities are now invading local boundaries through e-service and thereby intensifying competition between domestic and international educational institutions, given the fact that e-service is used to minimize administrative costs by enabling students to conduct such digital self-services. Therefore, it is no wonder that online ads of modern degree tend to pop up omnipresently on nearly every web page.

However, the main challenges that still need to be addressed in Ghana's systems include: how much emphasis higher education institutions must fasten to the reliability of the e-services they offer; as well as whether higher education institutions benefit from paying close attention to raising the quality of the e-services they provide to their students. Furthermore, the main objective of this study is to build a connection between the quality of e-services, expectations and their rate of use and the effect on the satisfaction that students end up receiving from eservices, as well as whether universities in Ghana will benefit from paying closer attention to optimizing the quality of the e-services they provide.

The case study model was fostered just so we could carry out this research in the real-life context of the student and get real-depth data (Saunders et al., 2007). The knowledge was gathered mainly using questionnaires from a sample of 360 undergraduate and graduate students from three colleges of the Kwame Nkrumah University of Science and Technology (KNUST). 


\subsection{THEORITICAL REVIEW 1.1.1. CUSTOMER SATISFACTION T HEORY (CSAT)}

Customer Satisfaction (CSAT) is a commonly used primary quality metric that measures how happy users are with the organisation's goods or services. It is a psychological condition, calculated by the expectations of the customer (Oliver, 1977; 1980). This is an indicator of how the products or services delivered by a firm meet or exceed consumer expectations. Customer satisfaction is identified as the number of customers or percentage of total customers whose engagement with a business, its products or its services (ratings) exceeds the specified satisfaction targets (Farris, Paul W 2010). In the literature, satisfaction antecedents are studied from various perspectives.

\subsubsection{SERVICE QUALITY THEORY (SERVQUAL)}

SERVQUAL is a multi-dimensional research method capable of capturing customer preferences and perceptions of a service in the five dimensions that are considered to represent service quality. SERVQUAL relies on the concept of expectationdisconfirmation, which practically means that service quality is interpreted as the extent to which customers' quality expectations regarding preconsumption are confirmed or disconfirmed by their post-consumption expectations. Once a team of academic researchers (A. Parasuraman, Valarie Zeithaml and Leonard L. Berry) first published the SERVQUAL questionnaire in 1985 to assess quality in the service sector[1], it marked a revolution in the calculation methods used for quality service research. The instrument's diagnostic value is provided by a service quality model, which forms the conceptual basis for scale production (i.e. instrument or questionnaire). The instrument has been widely used and found to be relatively robust in a number of environments and cultural settings. In the area of service quality it has become the standard measurement scale. This has faced some criticism from researchers, despite the long-standing interest in SERVQUAL and its variety of context-specific applications.

\subsubsection{TECHNOLOGY ACCAEPTANCE MODEL (TAM)}

In evaluating processes and parameters that consumers use in their evaluation of e-service quality, several dimensions or conceptualization of e-service quality have been defined by several authors and for the variety of online retail and service outlets based on the Technology Acceptance Model(TAM), Theory of Reasoned Action(TRA), Theory of Planned Behavior(TPB) and theories on e-service quality. Davis (1989) first modeled TAM to explain employees' acceptance of a new IT focused on two variables: Perceived Usefulness and Perceived Usefulness. In other phrases, people's behavior towards a technology (acceptance and manner of use) is determined by their desire to make easy use of the new technology and how it would allow them to perform their tasks more efficiently and effectively.

\subsection{PREVIOUS RESEARCHES IN THE FIELD}

\subsubsection{E-SERVICE QUALITY}

Santos (2003, p. 235) defined e-service quality as "an overall consumer assessment and judgment on efficiency and e-service quality in the online market." Parasuraman et al. (2005, p. 217) described e-service efficiency as "the extent with which a website renders efficient and reliable shopping, buying and delivering goods and services." Seven e-SQ dimensions defined by Parasuraman et al. (2005) are opted to be used in this study to measure presumed eservice quality of the service. The parameters constitute of four E-S-QUAL dimensions (efficiency, computer accessibility, compliance and privacy) and three E-RecS-QUAL parameters (responsibility, payment and contact). The first four dimensions of ESQ affect core online operation, while the remaining three dimensions contribute to service recovery. That is, if customers have no complaints with the platform, E-S-QUAL is related to consumer expectations of eservice quality (Yang and Fang, 2004), whereas ERecS-QUAL deals with online shopping complications (Nusair and Kandampully 2008).

Yet e-services act as a two-edged sword of competition. It also provides resources that make it much easier for customers to navigate, win their trust and encourage repurchase / revisit just as much as the web network makes it interesting competition. The volatile nature of online marketing thus suggests that online businesses need to build additional strategic capacity to overcome these environmental unique challenges (Wang, 2003; Chaffey, 2009). With eservices becoming the current competitive dimension among B2C / e-commerce firms, businesses need to work on delivering high-quality internet services regardless of the type of company and the product or service offered (Swaid \& Wigand, 2009; and Wang, 2003). More than $68 \%$ of customers leave a company due to poor service experience and other less important factors such as cost $(10 \%)$ and quality problems (17\%) (Feinberg et al., 2000 cited in Chaffey, 2009). In keeping with this, e-service is increasingly becoming a critical determining factor for attracting and retaining students; hence the need for e-service attention and success from institutions (Li \& Suomi, 2009). 


\begin{tabular}{|c|c|c|}
\hline AUTHORS & CONCEPTUALISATION & DIMENSIONS \\
\hline $\begin{array}{l}\text { Swaid \& Wigand } \\
(2009)\end{array}$ & $\begin{array}{l}\text { Explored e-retail service quality dimensions } \\
\text { on various loyalty types (loyalty } \\
\text { preferences, cost } \\
\text { complaining behavior) }\end{array}$ & $\begin{array}{l}\text { Website usability, Information quality, } \\
\text { Reliability, Responsiveness, Assurance } \\
\text { and Personalization }\end{array}$ \\
\hline $\begin{array}{l}\text { Cristobal et al. } \\
(2007)\end{array}$ & $\begin{array}{l}\text { PeSQ (Perceived Service Quality) is a } \\
\text { predictor of customer satisfaction and } \\
\text { loyalty for buyers and searchers of data. }\end{array}$ & $\begin{array}{l}\text { Web design, Customer service, } \\
\text { Assurance, and Order management }\end{array}$ \\
\hline $\begin{array}{l}\text { Parasuraman, } \\
\text { Zeithaml, \& } \\
\text { Malhotra (2005) }\end{array}$ & $\begin{array}{l}\text { E-ServQual Scale: Developed a more retail- } \\
\text { oriented scale integrating the dimensions of } \\
\text { digital service recovery }\end{array}$ & $\begin{array}{l}\text { Efficiency, fulfillment, system } \\
\text { availability, privacy; responsiveness, } \\
\text { compensation, contact. }\end{array}$ \\
\hline $\begin{array}{l}\text { Wolfinbarger \& } \\
\text { Gilly (2003) }\end{array}$ & $\begin{array}{l}\text { The researchers ' eTailQ dimensions were } \\
\text { used to predict overall quality correlation } \\
\text { across varied e-service users (browsers, } \\
\text { goal-oriented, regular consumers, books / } \\
\text { music, auction, etail, etc.). }\end{array}$ & $\begin{array}{l}\text { Completion / reliability, website } \\
\text { design, customer support and privacy } \\
\text { / security }\end{array}$ \\
\hline $\begin{array}{l}\text { Loiacono et al } \\
(2002)\end{array}$ & $\begin{array}{l}\text { Built } 12 \text { WebQual dimensions and used } \\
\text { them to predict consumers' intention to } \\
\text { purchase and revisit through product } \\
\text { websites (CDs and Books) and service } \\
\text { (airline and hotel reservations). }\end{array}$ & $\begin{array}{l}\text { Tailor-made communication, } \\
\text { confidence, response time, ease of } \\
\text { comprehension, intuitive operations, } \\
\text { visual appeal, creativity, emotional } \\
\text { appeal, clear image, online } \\
\text { Completeness, and Relative } \\
\text { Advantage. }\end{array}$ \\
\hline $\begin{array}{l}\text { Yoo \& Donthu } \\
\text { (2001) }\end{array}$ & $\begin{array}{l}\text { Conceived as' SiteQual' an e-service' online } \\
\text { shopping,' a place to browse, }\end{array}$ & $\begin{array}{l}\text { Ease of Use, Aesthetic Design, } \\
\text { Processing Speed, and Security }\end{array}$ \\
\hline
\end{tabular}

Table 1: Key contributions in understanding the concept of e-service quality

While in some dimensions the two structures (SERVQUAL and E-SQ) are equivalent, e-services have distinct features based on the content delivery system, service quality and product category (Collier \& Bienstock, 2006; Li \& Suomi, 2009; Swaid \& Wigand, 2009; Zeithaml et al., 2002); For example, some authors argue that the mere exclusion of physical persons, the technology-based delivery mechanism and the self-service elements in eservices indicate the need for dimensions such as trust, ease of use, website content and functionality at the expense of professionalism, courtesy, cleanliness, friendliness, etc. (Cox \& Dale, 2001; Li \& Suomi, 2009). Along with several other researchers from the fields of operation, efficiency, e-business and information management, etc., their work has provided a pool of expertise that offers insight into more field research and also serves as an invaluable guide to the industry. In the study of current eservices literature multiple dimensions of E-SQ have been discovered. Most of these dimensions cut through most studies; though definitions vary. Table 1 summarizes some of the contributors to the creation of E-SQ measurements based on literature and the main dimensions of current literature.

\subsubsection{E-SERVICE EXPECTATION}

Service quality perceptions have historically been conceptualized as the discrepancy between quality expectations and perceived service performance, based on the expectation-disconfirmation model
(Oliver, 1977, 1980) (Parasuraman et al., 1985, 1991a). As both the quality of the service and the level of prior expectations can impact the assessment of the service by a customer, and thus the degree of satisfaction for the provider, it is crucial for service providers to know how the customer arrives at a certain level of expectations, whether it is constant or can be affected and whether it is dimension specific. One aspect that influences the degree of expectations, found in previous research, is the customer's general demeanor towards service. Perhaps there is a distinction between positive and negative (Berry et al., 1993; Gwynne et al., 2000; Johnston, 1995).

According to (Oliver RL, 1980), the system for actual confirmation of information starts with the initial expectations of individuals regarding a particular knowledge that they may acquire before the discovery process. And the new information is embraced by individuals and used. Individuals shape impressions of the website after a time of initial use, that is to say, whether it can boost their awareness or not. In essence, they assess a website's perceived performance against their original expectations, and decide to what degree their expectations are true. Since expectations and quality perceptions of consumers can vary from one to the other, assurance can be positive when the actual result is better than expectations. In this case the customer would be satisfied. Nonetheless, confirmation can be negative if perceived output falls short of expectations, and the 
customer will be disappointed in this case (Liao C, et al 2007).

\subsubsection{CUSTOMER SATISFACTION}

In the marketing field, customer satisfaction has historically been studied as one of the important attitude variables which can influence consumer (student) behaviour. The majority of marketing literature satisfaction studies are based on the disconfirmation principle. This postulates that, the feeling of satisfaction is a function of contrasting experiences of the success of a good or service with expectations (Oliver, R. L, 1989).

Customers are known to rate products based on a standard set of parameters and attributes. Olshavsky and Miller (1972) and Olson and Dover (1976) advocated their study to control the actual quality of the product and their intention was to find out how the projected findings influence expectations. These studies have taken the discourse on making a distinction between expectations and perceived quality (Kucukosmanoglu, et al, 2010) In several research studies, scholars have been able to demonstrate that customer satisfaction has a strong emotional, i.e. affective, dimension (Westbrook, Robert A., 1991).

\subsubsection{USER FREQUENCY}

The level of e-service usage among customers / students is an significant issue in the competitive eservices environment. Number of studies indicate that loyalty is motivated by satisfaction, e-trust and standard of service. With tertiary institutions, Cleary has found out that institutional standards may also regulate the use of e-service for students. If students are expected to follow institutional requirements, then they would have no recourse but to do so. Customer / student loyalty was described as "a deep commitment to regularly repurchase or repatronize a preferred product / service in the future, culminating in recurrent purchases of the same brand or brand collection amid situational pressures and marketing strategies with the potential to trigger switching behaviors" (Oliver, 1999). The e-Loyalty system expands the conventional online loyalty model to customer behaviour. Cyr et al. (2007) defined eloyalty as an desire to revisit or make a future transaction from a website. Strauss et al. (2009) defines e-loyalty as "the favorable attitude of the customer on to an e-commerce website, which tends to lead the customer to repeat purchasing behaviour." Numerous researchers have sought to find relevant antecedents and their position in e-loyalty development. Price of e-service, e-satisfaction, corporate image, word-of-mouth contact, perceived value have been suggested as an antecedent of loyalty (Wieringa and Verhoef 2007; Patterson and Smith
2003) and these variables are also taken as a motivating force for competitive advantage and business success. Satisfaction is generated when an individual assumes the other person has not only productivity but also useful indices (Flavian et al 2006).

\section{RESEARCH HYPOTHESIS DEVELOPMENT AND CONCEPTUAL FRAMEWORK \\ 1.3. HYPOTHESIS \\ 1.3.1. THE IMPACT OF E-SERVICE EXPECTATION ON E-SERVICE QUALITY}

Perceived quality may reflect perceived product or service performance (Rust RT. Et al 1999). Quality measurement in relation to expectation is the most prevalent quality viewpoint (Nelson R. et al. 2005). From the perspective of expectations, quality is characterized by alignment with customer standards that may contribute to performance, reliability and other qualities that are important to customers in forming their quality perceptions (Nelson R. et al. 2005). The perceived level of quality may either confirm or disconfirm a pre-expectation. In addition, anticipation and the perceived level of disconfirmation have quite a positive impact on satisfaction. To this point, if it is considered that disconfirmation has occurred, consumer satisfaction will increase or decrease from the initial expectation (Bhattacharjee A. 2001).

Given these insights from literature, the study proposes that:

$H_{1}$ : Perceived E-service expectation has a positive influence on E-service quality among university students

\subsubsection{THE IMPACT OF E-SERVICE EXPECTATION ON E-SERVICE SATISFACTION}

In prior research the direct correlation between expectation and customer satisfaction was proposed. According to Bhattacherjee 2001, the direct connection between expectation and satisfaction can be explained by adaptation level theory, which states that humans evaluate stimuli relative to or as a deviation from an adapted level or baseline stimulus level, where that adapted level is defined by the nature of the stimulus, the psychological characteristics of the person experiencing. Therefore, the higher the expectations, the better the quality of the service or product and, conversely, the lower the expectations, the poorer the quality of the service or product.

Given these facts, we propose that; given these literary insights, the analysis suggests: 
$\mathrm{H}_{2}$ : Perceived E-Service Expectation has a positive influence on E-Service Satisfaction among university students.

1.3.3. THE IMPACT OF E-SERVICE EXPECTATION ON E-SERVICE USAGE FREQUENCY

E-service expectations increase the students' preferences to adopt e-service. Postacceptance expectation as per (Oliver RL, 1980) is established by the first-hand experience of the customers and is more practical (Bhattacharjee, 2001). This posttacceptance expectation is expressed as perceived usefulness in Bhattacherjee's research. Perceived usefulness can be interpreted as an individual belief or description of belief, such that perceived usefulness is a conceptual belief that stands out for IS usage (Davis F. 1989), usefulness is the only belief that reliably controls user expectation across the temporal stages of the use of information systems; thus, it is an acceptable presumption in the sense of the use of information systems. Perceived usefulness is an significant variable that influences user postadoption decisions, as users are likely to re-evaluate their early acceptance decisions at this point and make their decisions on prolonged use.

Given these insights from literature, the study proposes that:

$H_{3}$ : Perceived E-expectation has a positive influence on E-service usage frequency among university students.

\subsubsection{THE IMPACT OF E-SERVICE QUALITY ON E-SERVICE SATISFACTION}

It is held that appreciating e-service, which is a kind of self-service from the customer / student standpoint, is close to adopting new information technology (Parasuraman et al., 2005). Several literature-wide studies (Zeithaml et al. 2002; Loiacono et al. 2002; Yi \& Hwang 2003; Monsuwé et al. 2004; Parasuraman et al. 2005; Ramayah et al. 2012; Aladwan \& Smedley 2012; and Rare 2014) have relied on these theories to explain the use of customer expectations in evaluating E-SQ (as discussed above) and the resulting effect on consumer behavioral motivations. Hence, this work draws valid conclusions from these observations to conceptualize the relationship that emphasizes university E-SQ, student satisfaction, and utilization rate of university e-services.

Given these insights from literature, the study proposes that:

$H_{4}$ : perceived e-service quality has positive influence on student's satisfaction of university's e-service

\subsubsection{THE IMPACT OF E-SERVICE USAGE FREQUENCY ON E- SERVICE QUALITY}

For this study, the student loyalty (as told by the satisfaction level and perceived e-service quality) was calculated for terms of their rate of use of the university's digital services. A research by Cristobal et al. (2007) on the causality between perceived eservice quality, satisfaction and website loyalty between customers and data searchers found that website loyalty is determined significantly by satisfaction. Furthermore, Ramayah et al. (2012) attempted to examine the relationship between perceived consumer interest and user satisfaction and the resulting impact of satisfaction. It was concluded from their findings that perceived quality, which includes the dimensions of service quality, quality of information, and quality of processes, positively influences customer satisfaction, and that user satisfaction also directly affects the intention of continued use of the program. Kim-Soon et al. (2014) also found that e-services reacted positively to the eservices utilization rate to encourage education, research and interaction. According to Mohsan and Nawaz (2011), satisfaction is a very important measure of loyalty and while satisfaction can exist without loyalty, loyalty can hardly be without satisfaction. Nonetheless, they concluded that the three principles of e-service quality, satisfaction, and loyalty were for sure closely interdependent.

In view of these evidences, the study proposes that:

$H_{5}$ : Perceived frequency of usage on $E-$ Service has a positive influence on Quality of eservices among university students.

\subsubsection{THE IMPACT OF E-SERVICE USAGE FREQUENCY ON E- SERVICE SATISFACTION}

The level of electronic usage has a positive impact on satisfaction of the electronic service when the students' standards are met. The standard of eservices also has a driving impact on student usage frequency (Zeithaml et al. 2002; Loiacono et al. 2002; Yi \& Hwang 2003; Monsuwé et al. 2004; Parasuraman et al. 2005; Ramayah et al. 2012; Aladwan \& Smedley 2012; and Rare 2014). University prerequisite has also a regulating effect on frequency of usage to a certain degree. If students are expected to fulfill the requirement of universities, they have no choice but to do so. They may not be so pleased or fulfilled with the service, but they do have to fulfill their school requirements.

Given these insights from literature, the study proposes that:

$H_{6}$ : Perceived E-User Frequency has a positive influence on E-Satisfaction among university students. 


\subsection{CONCEPTUAL FRAMEWORK}

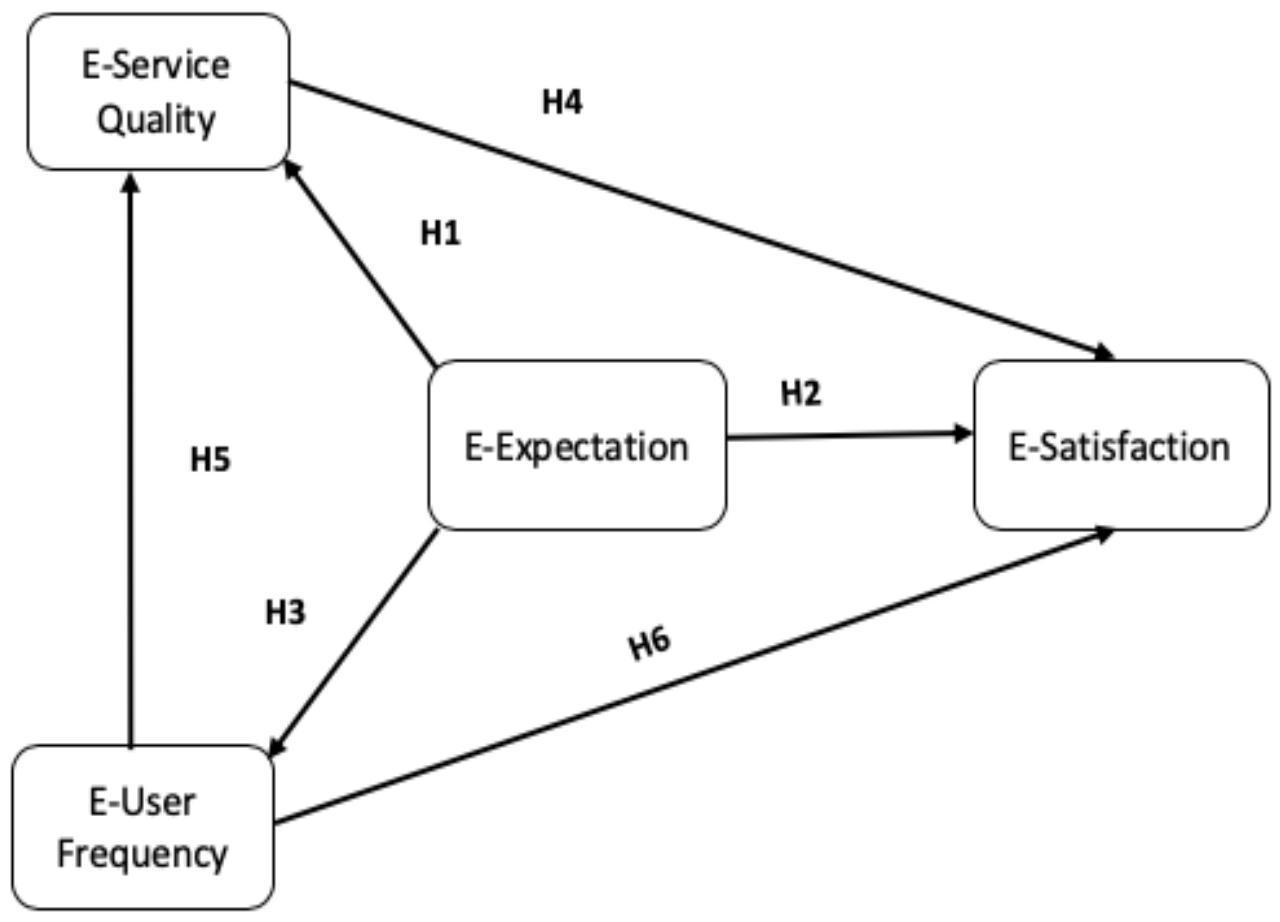

Figure 1: A conceptual framework of the study.

\section{METHODOLOGY}

\subsection{RESEARCH} SAMPLING

DESIGN

AN

The general scope of the analysis is a contrast between e-services in higher education institutions in Ghana. Kwame Nkrumah University of Science and Technology is the focal institutions used for this research.

The research design adopted for this research will follow both quantitative and qualitative approaches. This type of study design is usually used by researchers when there is a problem identified in an environment which should be addressed to ensure a fundamental understanding of challenges and derive means for solving the problem. According to (Yin, 1984) descriptive survey involves the collection of data aimed at answering questions concerning the present status of a phenomenon.

Data would be obtained from students at Kwame Nkrumah University of Science and Technology (KNUST). Chose to focus on KNUST as one of the first universities in the sub-region to introduce and pioneer internet-based teaching, research, learning and networking applications with established education stakeholders.

The questionnaire will be designed mainly for some of students. The questionnaire will provid with a covering letter which introduces the researcher and explains the purpose of the study, the method of responding and the security of respondent's information will also be assured in order to encourage high response rate. Each questionnaire is divided into two parts; the first part is based on the socio demographic information while the latter part is based on the knowledge, attitude and practice of the respondent.

\subsection{DATA ANALYSIS}

SEM-VB (Structural Equation Modeling-Variance Based) was used to test the exploration model using the software SmartPLS 3.0 (Ringle, Wende, and Becker, 2015). The primary reason for choosing SEM as a factual technique for this study is that SEM is presenting a synchronous investigation that prompts rapidly reliable evaluations (Isaac, Abdullah, Aldholay, and Ameen, 2019; Isaac, Abdullah, Ramayah, and Mutahar, 2017; Mutahar, Daud, Thurasamy, Isaac, and Abdulsalam, 2018).

\subsection{MEASUREMENT MODEL ASSESSMENT (RELIABILITY AND VALIDITY ANALYSIS)}

The individual Cronbach's alpha, the composite unwavering quality (CR), The normal change extricated (AVE), and the factor loadings surpassed the recommended worth (Kline, 2010; Hair, Black, Babin, and Anderson, 2010) as outlined in Table 2. How much the articles recognize among ideas or 
measure various develops is shown by discriminant legitimacy. Fornell-Larcker was utilized to examine the estimation model's discriminant legitimacy. Table 3 demonstrates the findings for discriminatory validity by using the Fornell-Larcker condition. It was found that the AVEs' square root on the diagonals is greater than the connections among develops (relating line just as section esteems), proposing a solid relationship between the idea and their separate markers in contrast with different ideas in the model (Fornell and Larcker, 1981; Chin, 1998). As per Hair et al. (2017), this shows great discriminant legitimacy. Moreover, exogenous builds have a connection of under 0.85 (Awang, 2014). Eventually, both buildings were pleased with their discriminatory validity.

Factor loading for indicators of latent constructs

\begin{tabular}{|c|c|c|c|c|c|c|}
\hline \multicolumn{7}{|c|}{ Factor loading for indicators of latent constructs } \\
\hline Variables & Construct & Loadings & AVE & CR & Rho_A & $\begin{array}{l}\text { Cronbach's } \\
\text { Alpha }\end{array}$ \\
\hline \multirow[t]{5}{*}{ E-service expectation } & & & 0.636 & 0.874 & 0.915 & 0.817 \\
\hline & EXP1 & 0.706 & & & & \\
\hline & EXP2 & 0.864 & & & & \\
\hline & EXP3 & 0.821 & & & & \\
\hline & EXP4 & 0.791 & & & & \\
\hline \multirow[t]{7}{*}{ E-service quality } & & & 0.668 & 0.947 & 0.940 & 0.937 \\
\hline & CON3 & 0.877 & & & & \\
\hline & DES4 & 0.723 & & & & \\
\hline & RES1 & 0.785 & & & & \\
\hline & RES2 & 0.796 & & & & \\
\hline & RES3 & 0.786 & & & & \\
\hline & RES4 & 0.865 & & & & \\
\hline \multirow[t]{5}{*}{ E-service satisfaction } & & & 0.717 & 0.910 & 0.866 & 0.866 \\
\hline & SAT1 & 0.753 & & & & \\
\hline & SAT2 & 0.880 & & & & \\
\hline & SAT3 & 0.855 & & & & \\
\hline & SAT4 & 0.891 & & & & \\
\hline \multirow[t]{5}{*}{ E-service user satisfaction } & & & 0.645 & 0.879 & 0.834 & 0.817 \\
\hline & USF1 & 0.827 & & & & \\
\hline & USF2 & 0.783 & & & & \\
\hline & USF3 & 0.866 & & & & \\
\hline & USF4 & 0.731 & & & & \\
\hline
\end{tabular}

${ }^{* *}$ Note: $C R=$ Composite Reliability, $A V E=$ Average Variance Extracted.

Table 3. Discriminant validity (Fornell-Larcker Criterial)

\begin{tabular}{|l|c|c|c|c|}
\hline & ESQ & ESE & ESS & ESUF \\
\hline ESQ & 0.798 & & & \\
\hline ESE & $\mathbf{0 . 5 5 7}$ & $\mathbf{0 . 8 1 7}$ & & \\
\hline ESS & 0.660 & 0.741 & $\mathbf{0 . 8 4 7}$ & $\mathbf{0 . 8 0 3}$ \\
\hline
\end{tabular}

* Note: Diagonals are the square root of the average variance derived while the other entries are the correlations. Key: ESQ-electronic service Quality, ESE-electronic service expectations, ESS-electronic service satisfaction, ESUF-electronic service usage frequency.

$* *$ Model fit $(N F I=0.432$, chi-square $=487.077$ 


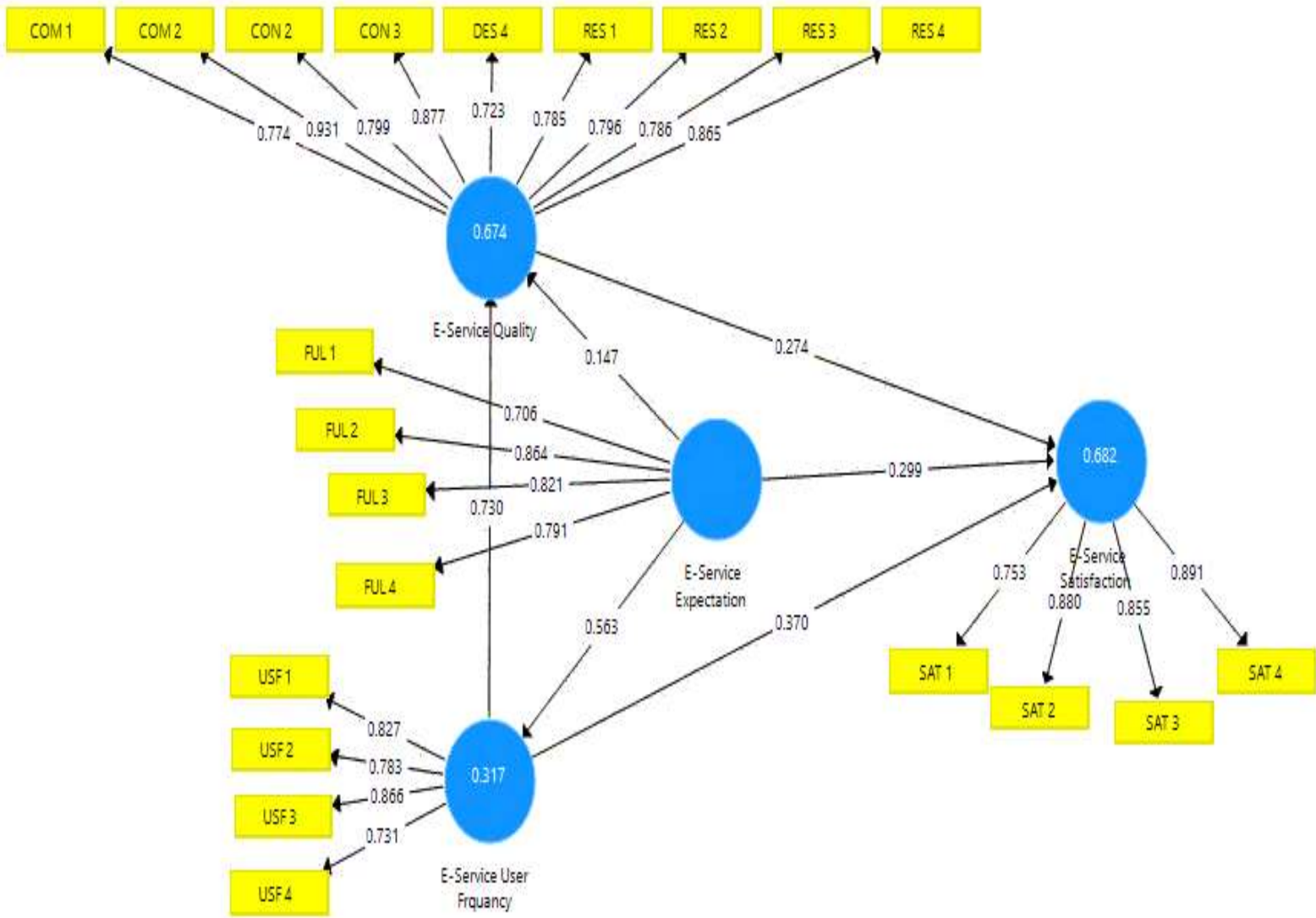

Presenting the final path model

1.8. STRUCTURAL MODEL ASSESSMENT

The Smart PLS model (Figure 2) is authenticated by Endogenous Latent Variable and Goodness of fit (GoF). The proposed goodness of fit is 0.5013 (RMSTheta) which surpasses the suggested threshold values of GoF $>.36$ suggested by Woetzel wt al., (2018). Thus, this study confirmed and concluded that the research model developed by the researcher has an on the whole or overall goodness of fit. Smart PLS software was used to observe the structural model as confirmed in the research. Path coefficient assessment (table 4 and figure 3 ) is included in the structural model indicating the power of the relations among the R-square value (Appendix 2), independent variable, and dependent variable. The structural model can be checked by beta $(\beta), \mathrm{R}^{2}$ and corresponding $t$-values using a bootstrapping technique with a resample of 5,000 (Hair, Hult, Ringle, \& Sarstedt, 2017). A 5 percent significance point $(p<0,05)$ is used as a statistical inference test. The degree of significance using the magnitude of the equivalent estimate of the factor between the constructs is shown in the corresponding t-value. 
Table 4 and figure 3 briefs the result of the structural model.

Path Coefficients along with their bootstrap values and ' $T$ ' Values

\begin{tabular}{|c|c|c|c|c|c|c|}
\hline Factors & $\begin{array}{l}\text { Original } \\
\text { sample } \\
(0)\end{array}$ & $\begin{array}{c}\text { Sample } \\
\text { mean(M) }\end{array}$ & $\begin{array}{l}\text { Standard } \\
\text { deviation } \\
\text { (STDEV) }\end{array}$ & $\begin{array}{l}\text { T statistics } \\
\text { (10/stdevl) }\end{array}$ & Decision & P values \\
\hline $\begin{array}{c}\text { E-service } \\
\text { expectation -> } \\
\text { E-service quality }\end{array}$ & 0.147 & 0.163 & 0.107 & 1.3969 & H1 = Not supported & 0.172 \\
\hline $\begin{array}{c}\text { E-service } \\
\text { expectation -> } \\
\text { E-service } \\
\text { satisfaction }\end{array}$ & 0.299 & 0.302 & 0.186 & 1.605 & H2 = Not supported & 00.109 \\
\hline $\begin{array}{c}\text { E-service } \\
\text { expectation -> } \\
\text { E-service usage } \\
\text { frequency } \\
\end{array}$ & 0.563 & 0.597 & 0.128 & 4.391 & H3 = Supported & 0.000 \\
\hline $\begin{array}{c}\text { E-service quality } \\
\text {-> E-service } \\
\text { satisfaction }\end{array}$ & 0.274 & 0.281 & 0.189 & 1.450 & H4 = Not supported & 0.148 \\
\hline $\begin{array}{l}\text { E-service usage } \\
\text { frequency -> E- } \\
\text { service quality }\end{array}$ & 0.730 & 0.719 & 0.096 & 7.585 & H5 = supported & 0.000 \\
\hline $\begin{array}{l}\text { E-service usage } \\
\text { frequency -> E- } \\
\text { service } \\
\text { satisfaction }\end{array}$ & 0.370 & 0.364 & 0.159 & 2.325 & H6 = supported & 0.002 \\
\hline
\end{tabular}

The relationship between E-service Expectation and E-service quality was not supported and insignificant with the original sample $(\beta)=0.147$, satistics $(\mathrm{t})=1.3969$ and significant value $(p=[0.172])>0.005$ indicates that E-service quality is not influenced directly and positively by E-service Expectation. The relationship between E-service Expectation and E-service satisfaction was not supported and insignificant with the original sample $(\beta)=0.299$, satistics $(t)=1.605$ and significant value $(p=[00.109])>0.005$ indicates that E-service satisfaction is not influenced directly and positively by E-service Expectation. The relationship between E-service Expectation and E-service quality was supported and significant. With the original sample $(\beta)=0.563$, satistics $(t)=4.391$ and significant value $(\mathrm{p}=[0.000])<0.005$, indicates that E-service usage frequency is influenced directly and positively by Eservice Expectation. The relationship between E- service Quality and E-service satisfaction was not supported and insignificant With the original sample $(\beta)=0.274$, satistics $(t)=1.450$ and significant value $(p=[0.148])>0.005$, It has been indicated that Eservice satisfaction is not influenced directly and positively by E-service Quality. The relationship between E-service Usage frequency and E-service quality was supported and significant. With the original sample $(\beta)=0.730$, satistics $(t)=7.585$ and significant value $(\mathrm{p}=[0.000])<0.005$, It indicates that E-service quality is influenced directly and positively by E-service Usage frequency. The relationship between E-service Usage frequency and E-service quality was supported and significant. With the original sample $(\beta)=0.370$, satistics $(t)=2.325$ and significant value $(\mathrm{p}=[0.002])<0.005$, It indicates that E-service quality is influenced directly and positively by E-service Usage frequency. 


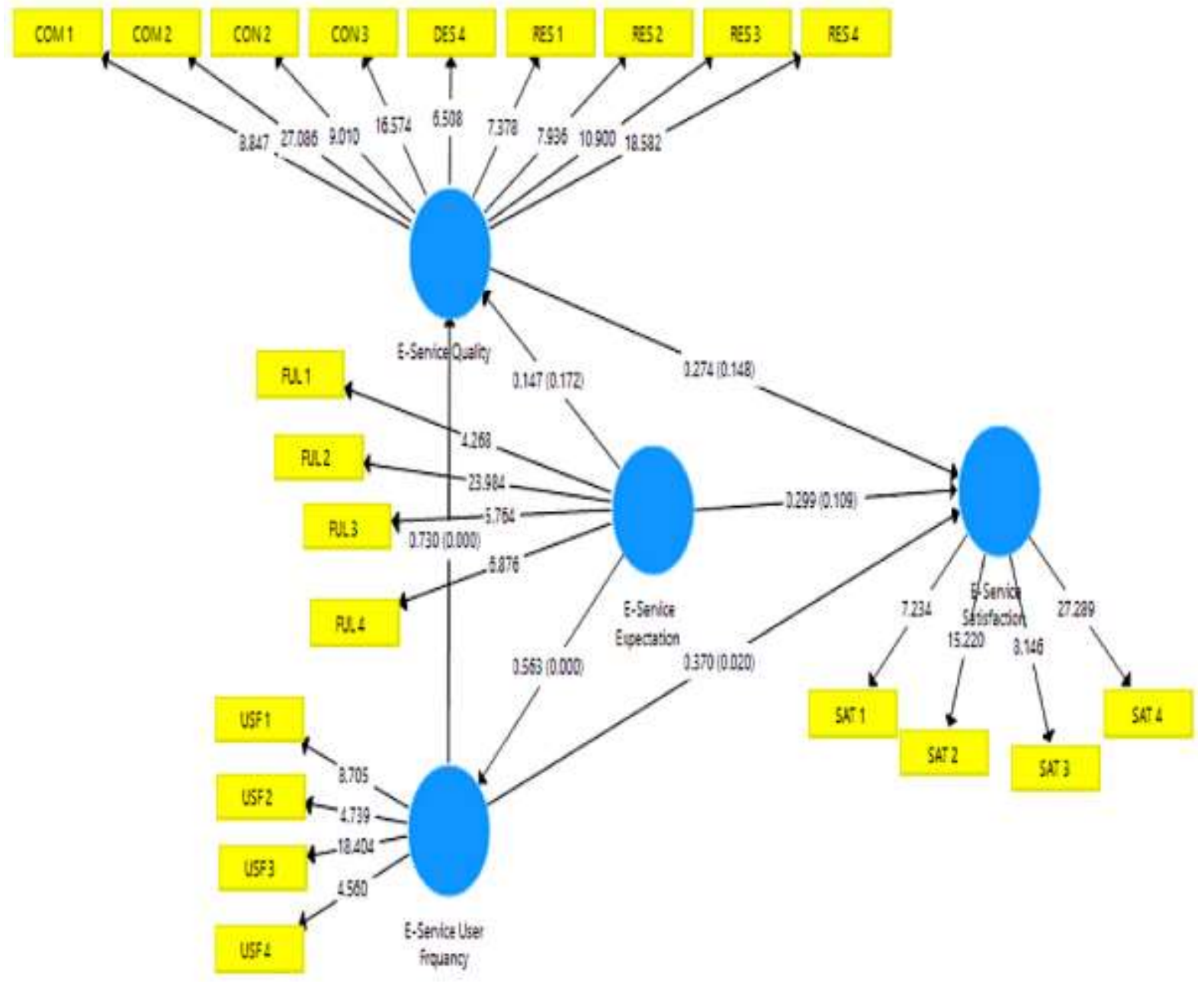

\section{DISCUSSION}

The study's primary focus was to analyze the correlation between KNUST's e-service quality (eSQ), e-service expectation, and e-service use frequency, and the impact it has on student satisfaction. Through the use of a much broader conceptualisation of E-SQ, CSAT and EDP, the findings of our study provide support for the instrument's applicability in pure service setting, such as an educational environment.

The descriptive results showed that while eservice quality and expectations for e-service were not satisfactory, students were somewhat impressed with the university's e-services; also, the frequency of use was high. The results also indicated that e-service quality and e-service expectations have a negative effect and a negative impact on satisfaction, but eservice usage frequency has had a significant positive effect on e-service quality and e-service satisfaction, thus supporting the study's hypotheses 5 and 6 . These results are consistent with some previous research findings by authors such as Wolfinbearger and Gilly (2003); Ozkan and Koseler (2009); Al-Mushasha and Nassuora (2012); Ramayah et al. (2012) and Sanayei and Jokar (2013). The insignificant non-supportive effect of e-service expectations directly on e-service satisfaction, except interposed by e-service usage frequency in the linkage; suggests the tendency for students to use frequency to serve as a conduit to transmit the positive effect of e-service expectation on e-service satisfaction. This finding reflects established literature in both the retail and educational settings on this topic. For example, in their study, Shapor et al. (2011) and Gummerus et al. (2004) denied the recognition of loyalty as an antecedent for satisfaction in the banking sector; which was extended by Mohsan and Nawaz (2011) that while loyalty could exist without it leading to customer satisfaction, loyalty could not exist without satisfaction. Other similar studies (see Cristobal et al., 2007; Sanayei \& Jokar, 2013) have reported similar mediating role of loyalty in the service qualityloyalty linkage. Further, Cristobal et al. (2007)'s findings on the causal relationship between e-service quality, satisfaction and website loyalty for buyers and knowledge searchers showed, among other things, that perceived e-service quality does not significantly predict website satisfaction (also in Sanayei \& Jokar, 2013); except through loyalty. This therefore means that the finding of this study with 
respect to hypotheses 5 to 6 largely affirm findings in existing literature. The study concluded that the average use of e-services offered by the university by the student was above average because the students considered the quality of e-services to be high. In this study the quality has no significant impact. There is hence an urgent need for the universities to improve the quality of the e-services delivered to students if they want to employ the full benefit of e-services to improve communication and cut administrative cost in the university's operations. They can do this by introducing policies and the necessary infrastructure to improve the quality of e-services and encourage the use of e-services among students, realizing the cost of investing in these infrastructure and the winwin advantage for both universities and students (Sutarso \& Auharmdi, 2011).

\section{CONCLUSION}

This study indicates that the frequency of eservice use has a significant positive and important impact on the quality of e-service and e-service satisfaction in institutions of higher learning in Ghana. The findings indicate that if e-service quality is upgraded, it would result in higher e-price levels due to the high use of e-services in firms and organizations, which in turn will positively affect their willingness to buy and re-purchase intent. According to initial expectations, expectations of the students were high because these platforms had not been successful or were not previously used. As far as the current study is concerned, the inference is that universities with low-quality e-services will have students finding their e-services unsatisfactory and therefore inconsistent in their usage to enhance learning and administrative communication. This would help the universities cut the cost of physically interacting with their students. Because of this, we further conclude that the quality of e-services can have both financial implications for universities in terms of reducing administrative costs, as well as a ripple impact on the perception of quality by students on the university's reputation and competitiveness. This is in line with the findings drawn by Sutarso \& Auharmdi (2011); Kim-Soon et al. (2014); and Kilburn \& Kilburn (2014).

\section{POLICY IMPLICATIONS}

The political ramifications of the results of this study are that first; higher education institutions must get to know the perceptions of their students and come to terms with the reality that the integration of quality e-services into their daily activities will not only be about serving their students with e-services, but that particular quality requirements must be agreed with the media as a matter of policy While, according to the current report, the level of usage of students has a significant impact on the satisfaction of students, the pursuit of high quality e-service is no longer a choice for administrators of higher education institutions, as the nature of demand for education these days needs them to be able to deliver successful onshore, remote and offshore education.

Second, the instability of competition in today's world climate in general, and the higher learning institutions in particular, is exacerbated daily by the effects of internet technology. With distance learning on e-platforms, tertiary institutions in Ghana today slowly invade each other's territories. As a result, e-services for certain organizations have become a threshold requirement. Since the internet is an open forum, pure online presence is considerably longer. The motivation for success lies in the innovativeness of institutions capable of providing their students with a high degree of standard of service in their online experience.

\section{LIMITATIONS AND SUGGESTIONS FOR FUTURE RESEARCH}

The spectrum of this research was restricted to the Kwame Nkrumah University of Science and Technology, and even though the students of this university exhibited behavior that can be contrasted with the behavior of students at other universities in Ghana, the generalizability of this study's results would be improved if samples were drawn across all public universities. All the same, this does not greatly reduce the applicability of this study's results but future research may either concentrate on other or all public universities. A comparative analysis between public, private and international universities may also be performed to find out if the characteristics exhibited by students in public universities match those exhibited by students in private and international universities. 
Appendix 1. OUTER LOADINGS

\begin{tabular}{|c|c|c|c|c|c|}
\hline & $\begin{array}{c}\text { Original } \\
\text { sample (0) }\end{array}$ & $\begin{array}{c}\text { Sample } \\
\text { mean(M) }\end{array}$ & $\begin{array}{c}\text { Standard } \\
\text { deviation } \\
\text { (STDEV) } \\
\end{array}$ & $\begin{array}{c}\mathrm{T} \\
\text { statistics(10/stdevl) }\end{array}$ & P Values \\
\hline $\begin{array}{c}\text { Com1<-E- } \\
\text { service quality }\end{array}$ & 0.774 & 0.769 & 0.087 & 8.847 & 0.000 \\
\hline $\begin{array}{c}\text { Com2<-E- } \\
\text { service quality }\end{array}$ & 0.931 & 0.926 & 0.034 & 27.086 & 0.000 \\
\hline $\begin{array}{c}\text { Con } 2<- \text { E-service } \\
\text { quality }\end{array}$ & 0.799 & 0.793 & 0.089 & 9.010 & 0.000 \\
\hline $\begin{array}{c}\text { Con3<-E-service } \\
\text { quality }\end{array}$ & 0.877 & 0.873 & 0.053 & 16.574 & 0.000 \\
\hline $\begin{array}{c}\text { DES4<-E- } \\
\text { service quality }\end{array}$ & 0.723 & 0.713 & 0.111 & 6.508 & 0.000 \\
\hline $\begin{array}{l}\text { FUL1<-E- } \\
\text { service } \\
\text { expectation }\end{array}$ & 0.706 & 0.672 & 0.166 & 4.268 & 0.000 \\
\hline $\begin{array}{c}\text { Full } 2<- \text { E-service } \\
\text { expectation }\end{array}$ & 0.864 & 0.872 & 0.036 & 23.984 & 0.000 \\
\hline $\begin{array}{c}\text { Full3<-E-service } \\
\text { expectation }\end{array}$ & 0.821 & 0.783 & 0.142 & 5.764 & 0.000 \\
\hline $\begin{array}{c}\text { Full4<-E-service } \\
\text { expectation }\end{array}$ & 0.791 & 0.764 & 0.115 & 6.876 & 0.000 \\
\hline $\begin{array}{c}\text { RES1<-E- } \\
\text { service quality }\end{array}$ & 0.785 & 0.761 & 0.106 & 7.378 & 0.000 \\
\hline $\begin{array}{c}\text { RES2<- E- } \\
\text { service quality } \\
\end{array}$ & 0.796 & 0.791 & 0.100 & 7.936 & 0.000 \\
\hline $\begin{array}{c}\text { RES3 <-E- } \\
\text { service quality }\end{array}$ & 0.786 & 0.788 & 0.072 & 10.900 & 0.000 \\
\hline $\begin{array}{c}\text { RES4 <-E- } \\
\text { service quality }\end{array}$ & 0.865 & 0.865 & 0.047 & 18.582 & 0.000 \\
\hline $\begin{array}{l}\text { SAT1<-E- } \\
\text { service } \\
\text { satisfaction }\end{array}$ & 0.753 & 0.762 & 0.104 & 7.234 & 0.000 \\
\hline $\begin{array}{c}\text { Sat } 2<- \text { E-service } \\
\text { satisfaction }\end{array}$ & 0.880 & 0.879 & 0.058 & 15.220 & 0.000 \\
\hline $\begin{array}{c}\text { Sat3<-E-service } \\
\text { satisfaction }\end{array}$ & 0.855 & 0.849 & 0.105 & 8.144 & 0.000 \\
\hline $\begin{array}{c}\text { Sat } 4<- \text {-E-service } \\
\text { satisfaction }\end{array}$ & 0.891 & 0.897 & 0.033 & 27.289 & 0.000 \\
\hline $\begin{array}{l}\text { USF1<-E- } \\
\text { service user } \\
\text { frequa } \\
\end{array}$ & 0.827 & 0.833 & 0.095 & 8.705 & 0.000 \\
\hline $\begin{array}{l}\text { USF2<-E- } \\
\text { service user } \\
\text { frequa }\end{array}$ & 0.783 & 0.760 & 0.165 & 4.739 & 0.000 \\
\hline $\begin{array}{l}\text { USF3<-E- } \\
\text { service user } \\
\text { frequa }\end{array}$ & 0.866 & 0.876 & 0.047 & 18.404 & 0.000 \\
\hline $\begin{array}{l}\text { USF4<-E- } \\
\text { service user } \\
\text { frequa }\end{array}$ & 0.731 & 0.708 & 0.160 & 4.560 & 0.000 \\
\hline
\end{tabular}

\section{REFERENCES}

1. Al-Adwan, A., \& Smedley, J. (2012). Implementing e-learning in the Jordanian higher education system: Factors affecting impact. International Journal of Education and Development Using Communication Technology, $8(1), 121-135$.
2. Alam, S.S., Z. Bakar, H.B. Ismail and M.N. Ahsan, 2008. Young consumers online shopping an empirical study. J. Internet Bus., 5: 81-98.

3. Al-Mushasha, N. F., \& Nassuora, A. B. (2012). Factors determining e-learning service quality in Jordanian higher education environment.pdf. Journal of Applied Science, 12(14), 1474-1480. 
4. Berry, L. L., Parasuraman A. \& Zeithaml, V.A (1993) Ten Lessons for improving Service Quality (Cambridge, MA, Marketing Science Institute).

5. Bhattacherjee A. Understanding information systems continuance: an expectation confirmation

model. MIS Quarterly. 2001;25(3):351-70.

6. Boso, N., Story, V. M., \& Cadogan, J. W. (2013). Entrepreneurial orientation, market orientation, network ties, and performance: Study of entrepreneurial firms in a developing economy. Journal of Business Venturing, 28, 708-727.

7. Calisir, F., \& Gumussoy, C. A. (2008). Internet banking versus other banking channels: Young consumers' view. International Journal of Information Management, 28(3), 215-221.

8. Chaffey, D. (2009). E-Business and E-Commerce Management: Strategy, Implementation and Practice (4th ed.). Prentice Hall.

9. Collier, J. E., \& Bienstock, C. C. (2006). Measuring service quality in e-retailing. Journal of Service Research, 8(3), 260-275. http://doi.org/10.1177/1094670505278867

10. Cox, J., \& Dale, B. G. (2001). Research and concepts service quality and e-commerce: an exploratory analysis. Managing Service Quality: An International Journal.

11. Cristobal, E., Flavián, C., \& Guinalíu, M. (2007). Perceived e-service quality (PeSQ): Measurement validation and effects on consumer satisfaction and website loyalty. Managing Service Quality: An International Journal, 17(3), 317-340. http://doi.org/10.1108/09604520710744326

12. Davis, F. (1989). Perceived usefulness, perceived ease of use, and user acceptance. MISQuarterly, 13, 319-339. http://doi.org/10.2307/249008

13. Douglas, S. and S. Craig, 1997. The changing dynamic of consumer behavior: Implications for crosscultural research. Int. J. Res. Market., 14: 379-395. DOI: 10.1016/S0167-8116(97)00026-8

14. Fassnacht, M., \& Koese, I. (2006). Quality of electronic services: Conceptualizing and testing a hierarchical model. Journal of Service Research, 9(1), 19-37. http://doi.org/10.1177/1094670506289531

15. Fitzsimmons, J. A., \& Fitzsimmons, M. J. (2006). Service Management: Operations, Strategy, and Information Technology (5th ed.). New York NY: McGraw-Hill/Irwin.

16. Ganguly, B., S.B. Dash, D. Cyr and M. Head, 2010. The effects of website design on purchase intention in online shopping: The mediating role of trust and the moderating role of culture. Int. J. Electronic Bus., 8: 302-330. DOI: 10.1504/IJEB.2010.035289

17. Georgiadis, E. S. C. K. (2009). E-service quality: comparing the perceptions of providers and customers. Managing Service Quality: An International Journal, 19(4), 410-430. http://doi.org/10.1108/09604520910971539

18. GWYNNE, A. L, DEVLIN, J.F \& ENNEW, C.T. (2000) The zone of tolerance: insights and influences, Journal of Marketing Management, 16, pp. 545-564.

19. Hair., J. F., Black, W. C., Babin, B. J., \& Anderson, R. E. (2014). Multivariate data analysis William C. Black Seventh Edition (7TH ed.). England: Pearson Education Limited.

20. Heinze, N., \& Hu, Q. (2006). The evolution of corporate web presence: A longitu- dinal study of large American companies. International Journal of Information Management, 26(4), 313-325.

21. Henry A., Abdul S. M., Emmanuel K. Q. (2017), "Linkages among E-Service Quality, Satisfaction, and Usage of E-Service within High Educational Environments", International Journal of Business and Social Research, 7(3), 10-26

22. Herskovitz, M.J., 1955. Cultural Anthropology. 1st Edn., Knopf, New York.

23. Johnston, $R$. (1995) The zone of tolerance: exploring the relationship between service transaction and satisfaction with the overall service, International Journal of Service Industry Management, 6(2), pp. 46-61

24. Junglas, I.A. and Watson, T. (2004), "National culture and electronic commerce", E-Service Journal, Vol. 3 No. 2, pp. 3-34.

25. Kausar, F. K., \& Bokhari, R. H. (2010). Exploring the factors associated with quality of website. Global Journal of Computer Science and Technology, 10(14), 37-45.

26. Kilburn, A., \& Kilburn, B. (2014). The mediating role of perceived value in the e-service qualityloyalty linkage among online higher education students end report. Research of Instructional Technology in Education, 1-10.

27. Kim-soon, N., Rahman, A., \& Ahmed, M. (2014). E-service quality in higher education and frequency of use of the service. International Education $\quad$ Studies, 7(3), 1-10. http://doi.org/10.5539/ies.v7n3pl

28. Kothari, C. R. (2004). Research methodology: Methods and techniques (2nd Ed). New Delhi: New Age International Limited Publishers.

29. Kroeber, A. and C. Kluckhohn, 1952. Culture. 1st Edn., Meridian Books, New York.

30. Leung, K., R.S. Bhagat, N.R. Buchan, M. Erez. and C.B. Gibson, 2005. Culture and international business: recent advances and their implications for future research. J. Int. Bus. Stud., 36: 357378. DOI: 10.1057/palgrave.jibs. 8400150

31. Liao C. Chen J-L. Yen DC Theory of planning behavior (TPB) and customer satisfaction in the continued use of e-service: An integrated model. Computers in Human Behavior. 2007;23(6):2804-22. doi: 10.1016/j.chb.2006.05.006.

32. Li, H., Liu, Y., \& Suomi, R. (2009). Measurement of e-service quality: An empirical study on online travel service. In European Conference on Information $S$ ystems.

33. Li, H., \& Suomi, R. (2009). A proposed scale for measuring e-service quality. International Journal of $U$ - and E-Service, Science and Technology, 2(1), 1-10. 
34. Loiacono, E. T., Watson, R. T., \& Goodhue, D. L. (2002). WebQual TM: A measure of website quality WebQual TM: A measure of website quality. Marketing Theory and Applications, 13(706), 432-438.

35. Mohsan, F., \& Nawaz, M. M. (2011). Impact of customer satisfaction on customer loyalty and intentions to switch: Evidence from banking sector of Pakistan. International Journal of Business and Social Science, 2(16), 263-270.

36. Monsuwé, T. P. Y., Dellaert, B. G. C., \& Ruyter, $K$. D. (2004). What drives consumers to shop online? A literature reviews. International Journal of Service Industry Management, 15(1), 102-121. http://doi.org/10.1108/09564230410523358

37. Nelson R, Todd P, Wixom B. Antecedents of information and system quality: an empirical examination within the context of data warehousing. Journal of Management Information System. 2005;21(4):199-236.

38. Nusair, K. and Kandampully, J. (2008), "The antecedents of customer satisfaction with online travel services: a conceptual model", European Business Review, Vol. 20 No. 1, pp. 4-19.

39. Oliver R. L. (1977) The effects of expectations and disconfirmation on post-exposure product evaluations, Journal of Applied Psychology, 62, April, pp. 246-250.

40. Oliver R. L. A cognitive model of the antecedents and consequences of satisfaction decisions. Journal of Marketing Research. 1980;17(4):460-9. [Google Scholar]

41. Ozkan, S., \& Koseler, R. (2009). Multidimensional students' evaluation of e-learning systems in the higher education context: An empirical investigation. Computers \& Education, 53(4), 1285-1296. http://doi.org/10.1016/j.compedu.2009.06.011

42. Pallant, J. (2007). SPSS Survival Manual: A step by step guide to data analysis using SPSS for windows (Third Edit). New York NY: Open University Press (McGraw Hill Education).

43. Parasuraman, A., Zeithaml, V.A. and Malhotra, A. (2005), "E-S-QUAL: a multiple-item scale for assessing electronic service quality", Journal of Service Research, Vol. 7 No. 3, pp. 213-33.

44. Pulse.com.gh (2015). UG, KNUST and UDS ranked best universities in Ghana. Viewed on 30th May 2016 at: http://pulse.com.gh/campus/ratings-ug-knustand-uds-ranked-best-universities-inghanaid4262026.html.

45. Ramayah, T., Wai, J., \& Lee, C. (2012). System characteristics, satisfaction and e-learning usage: A Structural Equation Model (SEM) 1. The Turkish Online Journal of Educational Technology, 11(2), 26-28.

46. Rareș, O. D. (2014). Measuring perceived service quality offline vs. online: a new PeSQ conceptual model. Procedia Economics and Finance, 15(14), 538-551. http://doi.org/10.1016/S2212-5671(14)00505X.
47. Reinders, M. J., Hagen, M. Van, \& Frambach, $R$. T. (2007). Customer evaluations of self-service technologies in public transport. Association for European Transport and contributors.

48. Rust RT. Inman JJ. Jia J. Zahorik A What you don't know about customer-perceived quality: the role of customer expectation distributions. Marketing Science. 1999;18(1):7792. doi: 10.1287/mksc.18.1.77.

49. Sanayei, A., \& Jokar, A. (2013). Determining the effect of electronic services quality on electronic satisfaction and positive word of mouth (case study): Different branches of shiraz mellat bank customers. International Journal of Academic Research in Accounting, Finance and Management Sciences, 3(4), 103-111. http://doi.org/10.6007/IJARAFMS/v3-i4/360.

50. Santos, J. (2003). E-service quality: a model of virtual service quality dimensions. Managing Service Quality: An International Journal, 13(3), 233-246.

http://doi.org/10.1108/09604520310476490.

51. Saunders, M., Lewis, P., \& Thornhill, A. (2007). Research Methods for Business Students (4th Editio). Edinburgh Gate: Pearson Education Limited.

52. Shapor, A., Jahromi, S., Ahmadi, E., Fakhravari, F., \& Adiby, P. M. (2011). The examination electronic services quality of sina bank with $E$ SERVQUAL model in Shiraz Branches. International Conference on Advancements in Electronics and Power Engineering (pp. 78-82). Bangkok.

53. Sohn, C., \& Tadisina, S. K. (2008). Development of e-service quality measure for internet-based financial institutions. Total Quality Management \& Business Excellence, 19 (February), 903-918. http://doi.org/10.1080/14783360802224412

54. Straub, D., Keil, W., Brenner, M. and Walter, $H$. (1997), "Testing the technology acceptance model across cultures: a three country study", Information and Management, Vol. 33 No. 1, pp. 1-11.

55. Sutarso, Y., \& Auharmdi, A. (2011). Promotion of E-Technology-Based Services : A Case Study of E-Service Quality at a University in Indonesia. International Journal of Business and Information, 6(1), 112-133.

56. Swaid, S. I. (2008). Developing an instrument for measuring electronic shopping service quality: ESQUAL. In Southern Association for Information Systems Conference (pp. 1-5).

57. Swaid, S. I., \& Wigand, R. T. (2009). Measuring the quality of e-service: scale development and initial validation. Journal of Electronic Commerce Research, 10(1), 13-28.

58. Times Higher Education (2019). Jiangsu University Asia Ranking. Viewed on 15 July 2019 at: https://www.timeshighereducation.com

59. Tsaur, S.-H., Lin, C.-T.I. and Wu, C.-S. (2005), "Cultural differences of service quality and behavioural intention in tourist hotels", Journal of Hospitality and Leisure Marketing, Vol. $13 \mathrm{No}$. 1, pp. 41-63. 
60. Vankatesh, V., Morris, M. G., Davis, G. B., \& Davis, F. D. (2003). User acceptance of information technology: Toward a unified view. MIS Quarterly, 27(3), 425-478. http://doi.org/10.2307/30036540

61. Wang, M. (2003). Assessment of E-Service Quality via E-Satisfaction in E-Commerce Globalization. Electronic Journal of Information Systems in Developing Countries. 11(10) 1-4.

62. Wolfinbarger, M., \& Gilly, M. C. (2003). eTailQ: Dimensionalizing, measuring and predicting retail quality. Journal of Retailing, 79, 183-198. http://doi.org/10.1016/S0022-4359(03)00034-4.

63. Yang, Z. and Fang, X. (2004), "Online service quality dimensions and their relationships with satisfaction: a content analysis of customer review of securities brokerage services", International Journal of Service Industry Management, Vol. 15 No. 3, pp. 302-26.

64. (Yang n.d.)Yi, M. Y., \& Hwang, Y. (2003). Predicting the use of web-based information systems: Self-efficacy, enjoyment, learning goal orientation, and the technology acceptance model. International Journal of Human Computer Studies, 59, 431-449. http://doi.org/10.1016/S1071-5819(03)00114-9.

65. Yoo, B., \& Donthu, N. (2001). Developing a scale to measure the perceived quality of an Internet shopping site (SITEQUAL). Quarterly Journal of Electronic Commerce, 2(1), 31-47. Retrieved from

http://people.hofstra.edu/Boonghee Yoo/papers/ 2001_QJEC_SITEQUAL.pdf

66. Zeithaml, V. A., Parasuraman, A., \& Malhotra, A. (2002). Service quality delivery through websites: A critical review of extant knowledge. Journal of the Academy of Marketing Science, 30(4), 362375. http://doi.org/10.1177/009207002236911 